\title{
Pharmacodynamic genetic polymorphisms affect adverse drug reactions of haloperidol in patients with alcohol-use disorder
}

This article was published in the following Dove Press journal:

Pharmacogenomics and Personalized Medicine

7 July 2017

Number of times this article has been viewed

\section{Mikhail Sergeevich}

Zastrozhin, ${ }^{1,2}$ Vadim

Markovich Brodyansky, ${ }^{3}$

Valentin Yurievich Skryabin, ${ }^{4}$

Elena Anatolievna Grishina, ${ }^{5}$

Dmitry Vladimirovich

Ivashchenko, ${ }^{5}$ Kristina

Anatolievna Ryzhikova, ${ }^{5}$

Ludmila Mikhaylovna

Savchenko,' Alexander

Olegovich Kibitov, ${ }^{3}$ Evgeny

Alekseevich Bryun, ${ }^{1,4}$ Dmitry

Alekseevich Sychev $^{6}$

'Department of Addictology, Russian

Medical Academy of Continuous

Professional Education of the Ministry of

Health of the Russian Federation, Moscow,

Russia; ${ }^{2}$ Moscow Research and Practical

Centre on Addictions of the Moscow

Department of Healthcare, Center for the Prevention of Dependent Behavior,

Moscow, Russia; ${ }^{3}$ Federal Medical Research

Centre of Psychiatry and Addictology,

Laboratory of Molecular Genetics, Moscow,

Russia; ${ }^{4}$ Moscow Research and Practical

Centre on Addictions of the Moscow

Department of Healthcare, Department of Addictology, Moscow, Russia; ${ }^{5}$ Russian

Medical Academy of Continuous

Professional Education of the Ministry of

Health of the Russian Federation, Research

Centre, Moscow, Russia; ${ }^{6}$ Russian Medical

Academy of Continuous Professional

Education of the Ministry of Health of the

Russian Federation, Department of Clinical

Pharmacology and Therapy, Moscow, Russia

Correspondence: Mikhail Sergeevich

Zastrozhin

Moscow Research and Practical Centre on Addictions of the Moscow Department of Healthcare, 37/I Lyublinskaya Street,

Moscow 109390, Russia

Tel +7 4991783505

Email rudnmed@yandex.ru
Background: Antipsychotic action of haloperidol is due to blockade of $\mathrm{D}_{2}$ receptors in the mesolimbic dopamine pathway, while the adverse drug reactions are associated with striatal $\mathrm{D}_{2}$ receptor blockade. Contradictory data concerning the effects of genetic polymorphisms of genes encoding these receptors and associated structures (catechol-O-methyltransferase [COMT], glycine transporter and gene encoding the density of $\mathrm{D}_{2}$ receptors on the neuronal membrane) are described.

Objective: The objectives of this study were to evaluate the correlation between DRD2, SLC6A3 (DAT) and COMT genetic polymorphisms and to investigate their effect on the development of adverse drug reactions in patients with alcohol-use disorder who received haloperidol.

Patients and methods: The study included 64 male patients (average age $41.38 \pm$ 10.14 years, median age 40 years, lower quintile [LQ] 35 years, upper quintile [UQ] 49 years). Bio-Rad CFX ManagerTM software and "SNP-Screen" sets of "Syntol” (Russia) were used to determine polymorphisms rs4680, rs1800497, rs1124493, rs2242592, rs2298826 and rs2863170. In every "SNP-Screen" set, two allele-specific hybridizations were used, which allowed to determine two alleles of studied polymorphism separately on two fluorescence channels.

Results: Results of this study detected a statistically significant difference in the adverse drug reaction intensity in patients receiving haloperidol with genotypes $9 / 10$ and 10/10 of polymorphic marker SLC6A3 rs28363170. In patients receiving haloperidol in tablets, the increases in the UKU Side-Effect Rating Scale (UKU) score of $9.96 \pm 2.24$ (10/10) versus $13 \pm 2.37$ (9/10; $p<0.001)$ and in the Simpson-Angus Scale (SAS) score of $5.04 \pm 1.59(10 / 10)$ versus $6.41 \pm$ $1.33(9 / 10 ; p=0.006)$ were revealed.

Conclusion: Polymorphism of the SCL6A3 gene can affect the safety of haloperidol, and this should be taken into account during the choice of drug and its dosage regimen.

Keywords: haloperidol, pharmacogenetics, DRD2, COMT, DAT, alcohol addiction, alcoholuse disorder

\section{Background}

Haloperidol is a butyrophenone-derivative antipsychotic medication. Guidelines recommend haloperidol for treatment of alcohol-use disorders in patients with alcohol-related psychosis. ${ }^{1,2}$ According to the Russian protocols of medical care, the main indication for haloperidol treatment in patients with substance-use disorders is the exacerbation of craving to psychoactive substances with psychomotor agitation. ${ }^{22}$ The use of haloperidol can cause a variety of adverse drug reactions (dystonia, tremor, rigidity, akinesia, akathisia, etc.). 
Antipsychotic action of haloperidol is due to blockade of $\mathrm{D}_{2}$ receptors in the mesolimbic dopamine pathway, while the adverse drug reactions are associated with striatal $\mathrm{D}_{2}$ receptors blockade. Dopamine $\mathrm{D}_{2}$ receptors are encoded by the DRD2 gene. It is known that Taq1A polymorphism (rs1800497; g.32806C $>$ T) of the DRD2 gene reduces density of striatal $\mathrm{D}_{2}$ receptors and probably changes their affinity. ${ }^{18}$ The results of both in vitro ${ }^{23}$ and in vivo ${ }^{19}$ studies indicate a $40 \%$ reduction in the density of striatal $\mathrm{D}_{2}$ receptors in the carriers of mutant $\mathrm{T}$ allele (also called A1 allele) of the Taq1 A polymorphism (rs 1800497). Mutant T-allele carriers have a lower risk of dyskinesia development. The results of two meta-analyses showed an increased frequency of late dyskinesia development in patients with allele C (A2) in comparison with the mutant T-allele carriers. ${ }^{3,27}$ At the same time, individuals with one $\mathrm{C}$ allele had a $30 \%$ increased risk of dyskinesia development, while the carriers of two $\mathrm{C}$ alleles conferred a $30 \%$ more risk. Therefore, homozygous $\mathrm{CC}$ individuals have an increased risk of late dyskinesia development compared to homozygous TT patients.

The dopamine transporter (encoded by SCL6A3 or DAT1 gene) is a transmembrane transporter that clears dopamine from the synaptic cleft. DAT-gene polymorphisms change the dopamine concentration in the synaptic cleft and affect the nerve impulse transmission. It was found that individuals with clinical signs of late dyskinesia have lower levels of transport protein. ${ }^{26}$ Currently, rs 28363170 polymorphism of the SCL6A3 gene is mostly explored. It has been shown by Guzey et $\mathrm{al}^{8}$ that patients with different allelic variations of this polymorphism have different rates of ADR development. However, the results of population studies in Jewish and Indian populations revealed no correlation between DAT1gene polymorphisms and late dyskinesia development. ${ }^{9,20}$ Later, it was confirmed in other population studies. ${ }^{13,25}$

Another dopamine-related gene examined in several pharmacogenetic studies of late dyskinesia is the gene encoding catechol-O-methyltransferase (COMT). Basically, dopamine is removed from the synaptic cleft by the process of presynaptic reuptake, but it can also be degraded by COMT. ${ }^{15}$ Additionally, this secondary mechanism of dopamine degradation by COMT is dominating in the frontal cortex. One of the functional polymorphisms in the COMT gene that codes COMT is rs4680 (Val158Met) polymorphism coding an amino acid change from valine (val) to methionine (met) at codon 158. The frequency of the met allele of the COMT polymorphism in different ethnic groups is $36 \%-48 \%$. It was shown that the presence of the met allele decreases the COMT activity by $25 \%$ compared to the val-containing enzyme activity. ${ }^{12}$ This results in lower synaptic dopamine concentrations in val-allele carriers due to their rapid degradation. The blockade of dopamine receptors by antipsychotics is followed by compensatory increases in receptor density and resulting hypersensitivity, which leads to dyskinesia development. As val-allele carriers have lower synaptic dopamine concentrations, the use of antipsychotics further reduces dopamine receptor binding. This results in compensatory response with subsequent dyskinesia.

The results of population studies in Japanese and Chinese populations revealed no correlation between Val108Met and extrapyramidal disorders. ${ }^{14,24}$ The results of meta-analysis ${ }^{4}$ of five studies with 1,089 patients (382 suffering from late dyskinesia and 707 with no extrapyramidal disorders) showed that met-allele carriers have a lower risk of late dyskinesia development (odds ratio $[\mathrm{OR}]=0.66$ ). The authors concluded that patients with val/val genotype have a $51 \%$ increased risk of late dyskinesia development. This polymorphism was also explored in the context of acute extrapyramidal disorders. ${ }^{29}$ The effect of genes encoding other enzymes involved in dopamine metabolism (such as monoamine oxidase A and B) on the development of extrapyramidal disorders was also studied, but it was not confirmed in the clinical studies in Japanese and European populations. ${ }^{14,16}$

The objective of this study was to evaluate the correlation between the DRD2, SLC6A3 (DAT) and COMT genetic polymorphisms and the development of adverse drug reactions in patients with alcohol-use disorder who received haloperidol.

\section{Patients and methods}

The study included 64 male patients (average age 41.38 \pm 10.14 years; median age 40 years, lower quantile [LQ] 35 years; upper quantile [UQ] 49 years) with alcohol-use disorder who were hospitalized in Moscow Research and Practical Centre on Addictions of the Moscow Department of Healthcare. During the exacerbation of compulsive alcohol use, patients received haloperidol in tablets (manufactured by LLC "OZON", Ghigulevsk, Russia) at a dose of 5.0 [Q1 and Q3: 3.0; 6.0] mg per day (44 patients, single use) and injections (manufactured by CAC "Bryntsalov-A", Moscow, Russia) at a dose of 5.0 [Q1 and Q3: 5.0; 5.0] mg per day (19 patients, single use). The inclusion criteria were 5-day haloperidol therapy in tablets or injections and age of 18-75 years. The exclusion criteria were presence of any other antipsychotics in the treatment regimen, creatinine clearance values $<50 \mathrm{~mL} / \mathrm{min}$, creatinine concentration in plasma $\geq 1.5 \mathrm{mg} / \mathrm{dL}$ ( $133 \mathrm{Umol} / \mathrm{L}$ ), body weight $<60 \mathrm{~kg}$ or $>100 \mathrm{~kg}$ and presence of any contraindications for haloperidol use. 
Venous blood samples collected in vacuum tubes VACUETTE ${ }^{\circledR}$ (Greiner Bio-One, Kremsmuenster, Austria) on the sixth day of the haloperidol therapy were used for genotyping. The real-time polymerase chain reaction was performed using DNA amplifiers "Dtlite" of DNA Technology (Moscow, Russia). CFX96 Touch Real Time System with CFX Manager software of Bio-Rad Laboratories Inc. (Hercules, CA, USA) and "SNP-screen" sets of "Syntol" (Moscow, Russia) were used to determine polymorphisms rs4680, rs1800497, rs1124493, rs2242592, rs2298826 and rs2863170. In every "SNP-screen" set, two allele-specific hybridizations were used, which allowed to determine two alleles of studied polymorphism separately on two fluorescence channels.

The haloperidol efficacy was evaluated using the Scale of Pathological Addiction (SoPA), and the haloperidol safety was evaluated using the UKU Side-Effect Rating Scale (UKU) and Simpson-Angus Scale (SAS) for extrapyramidal symptoms. Scaling was performed the day before the haloperidol therapy and after 5-day therapy. A higher difference in scale scores indicated a decreased safety of the therapy.

Statistical analysis of the results was performed with non-parametric methods using the "Statistica v.10.0" software (StatSoft; Dell Statistica, Tulsa, OK, USA). The normality of sample distribution was evaluated using the Shapiro-Wilk $W$-test and was taken into account when choosing a method. The differences were considered as statistically significant at $p<0.05$ (statistical power in excess of $80 \%$ ). To compare two independent groups of patients with different genotypes, Mann-Whitney $U$-test was used.

All quantitative data are shown as arithmetic mean \pm standard deviation $(\mathrm{M} \pm \mathrm{SD}$ ) or median (lower quintile; upper quintile) (Me [LQ; UQ]).
This research was approved by the ethics committee of Peoples' Friendship University of Russia, and all patients provided informed consent.

\section{Results}

Genotyping results are shown in Table 1.

The results of psychometric tests and efficacy scaling are shown in Table 2.

Data concerning comparison of haloperidol efficacy and safety in patients with different genotypes of polymorphic markers are shown in Table 3 (for patients taking haloperidol in tablets) and Table 4 (for patients taking haloperidol in injections).

\section{Discussion}

Numerous pharmacogenetic studies of haloperidol have been conducted. Some of them confirm that genetic polymorphisms

Table 2 Results of psychometric investigation of patients (efficacy and safety of haloperidol)

\begin{tabular}{lllll}
\hline Scale & $\begin{array}{c}\text { Before the } \\
\text { therapy }\end{array}$ & $\begin{array}{l}\text { After the } \\
\text { therapy }\end{array}$ & Dynamics & p-values* \\
\hline All patients & & & \\
SoPA & $24.29 \pm 3.08$ & $13.54 \pm 3.19$ & $-10.78 \pm 1.35$ & $<0.00 \mathrm{I}$ \\
UKU & $8.52 \pm 3.39$ & $19.9 \pm 2.28$ & $11.38 \pm 2.74$ & $<0.00 \mathrm{I}$ \\
SAS & $2.6 \pm 1.68$ & $8.13 \pm 1.1 \mathrm{I}$ & $5.57 \pm 1.58$ & $<0.00 \mathrm{I}$ \\
Group who received haloperidol in tablet form & \\
SoPA & $24.1 \mathrm{I} \pm 3.06$ & $13.43 \pm 3.25$ & $-10.7 \pm 1.44$ & $<0.00 \mathrm{I}$ \\
UKU & $8.64 \pm 3.43$ & $19.8 \pm 2.43$ & $11.18 \pm 2.74$ & $<0.00 \mathrm{I}$ \\
SAS & $2.77 \pm 1.74$ & $8.18 \pm 1.21$ & $5.48 \pm 1.69$ & $<0.00 \mathrm{I}$ \\
Group who received haloperidol in injection form & \\
SoPA & $24.68 \pm 3.16$ & $13.79 \pm 3.12$ & $-10.95 \pm 1.13$ & $<0.00 \mathrm{I}$ \\
UKU & $8.26 \pm 3.36$ & $20.16 \pm 1.95$ & $11.84 \pm 2.75$ & $<0.00 \mathrm{I}$ \\
SAS & $2.21 \pm 1.5 \mathrm{I}$ & $8 \pm 0.88$ & $5.79 \pm 1.32$ & $<0.00 \mathrm{I}$ \\
\hline
\end{tabular}

Notes: *t-test for dependent variables. Data presented as mean \pm SD.

Abbreviations: SoPA, Scale of Pathological Addiction; UKU, UKU Side-Effect Rating Scale; SAS, Simpson-Angus Scale.

Table I Genotypes and allele frequencies of COMT, DRD2, SLC6A5 and SLC6A3 polymorphisms in patients treated with haloperidol

\begin{tabular}{|c|c|c|c|c|c|c|c|c|c|c|c|c|}
\hline \multirow{2}{*}{$\frac{\text { Polymorphisms }}{\text { COMT (rs4680) }}$} & \multirow{2}{*}{$\begin{array}{l}\mathbf{n} \\
\mathbf{G G}\end{array}$} & \multirow[t]{2}{*}{$\%$} & \multirow{2}{*}{$\begin{array}{l}\text { GA } \\
\text { GA }\end{array}$} & \multirow[t]{2}{*}{$\%$} & \multirow{2}{*}{$\begin{array}{l}\mathbf{n} \\
\mathbf{A A}\end{array}$} & \multirow[t]{2}{*}{$\%$} & \multirow{2}{*}{$\begin{array}{l}\mathbf{n} \\
\mathbf{G}\end{array}$} & \multirow[t]{2}{*}{$\%$} & \multirow{2}{*}{$\begin{array}{l}\mathbf{n} \\
\mathbf{A}\end{array}$} & \multirow[t]{2}{*}{$\%$} & \multicolumn{2}{|c|}{ H-W equilibrium } \\
\hline & & & & & & & & & & & $\chi^{2}$ & $p$ \\
\hline & 14 & 22 & 31 & 49 & 18 & 29 & 59 & 47 & 67 & 53 & 0.009 & 0.925 \\
\hline \multirow[t]{2}{*}{ DRD2 (rs / 800497) } & $\mathrm{CC}$ & & CT & & TT & & C & & $\mathbf{T}$ & & $\chi^{2}$ & $\mathbf{p}$ \\
\hline & 41 & 65 & 20 & 32 & 2 & 3 & 102 & 81 & 24 & 19 & 0.0254 & 0.815 \\
\hline \multirow[t]{2}{*}{ DRD2 (rs I I 24493) } & TT & & TG & & GG & & $\mathbf{T}$ & & $\mathbf{G}$ & & $\chi^{2}$ & $p$ \\
\hline & 5 & 8 & 30 & 48 & 28 & 44 & 40 & 32 & 86 & 68 & 0.615 & 0.433 \\
\hline \multirow[t]{2}{*}{ DRD2 (rs2242592) } & GG & & GA & & AA & & G & & A & & $\chi^{2}$ & $p$ \\
\hline & 5 & 8 & 30 & 48 & 28 & 44 & 40 & 32 & 86 & 68 & 0.615 & 0.433 \\
\hline \multirow[t]{2}{*}{ SLC6A5 (rs2298826) } & AA & & AG & & GG & & A & & $\mathbf{G}$ & & $\chi^{2}$ & $p$ \\
\hline & 8 & 13 & 29 & 46 & 26 & 41 & 45 & 36 & 81 & 64 & $<0.001$ & 0.984 \\
\hline \multirow[t]{2}{*}{ SLC6A3* (DAT) (rs28363I 70) } & $10 / 10$ & & $9 / 10$ & & $9 / 9$ & & 10 & & 9 & & $\chi^{2}$ & $p$ \\
\hline & 33 & 54 & 26 & 43 & 2 & 3 & 92 & 75 & 30 & 25 & 1.359 & 0.244 \\
\hline
\end{tabular}

Note: *Two patients with genotypes $6 / 10$ and $7 / 10$ of polymorphic marker rs28363/70 of gene SLC6A3 have been excluded from the analysis. Abbreviation: $\mathrm{H}-\mathrm{W}, \mathrm{Hardy}-$ Weinberg. 


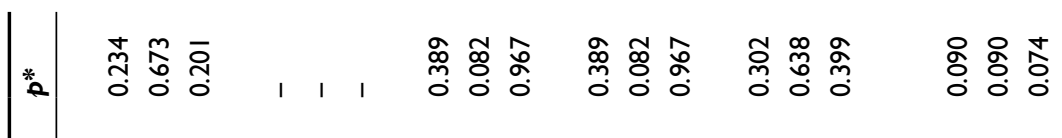

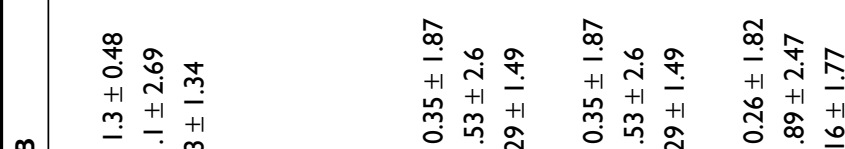
œ = \&은ㄷㅇㅇำ

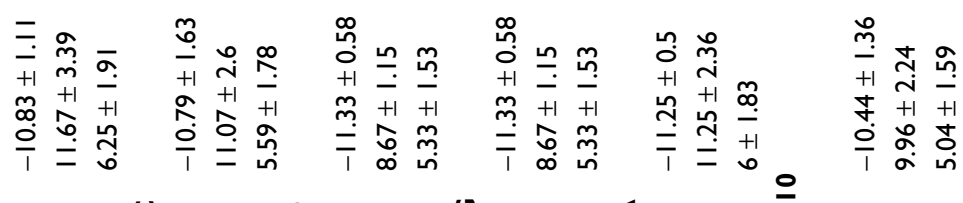
产 要

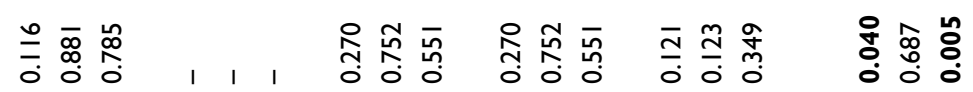

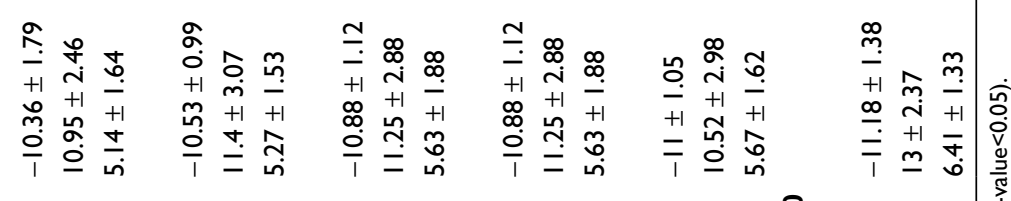

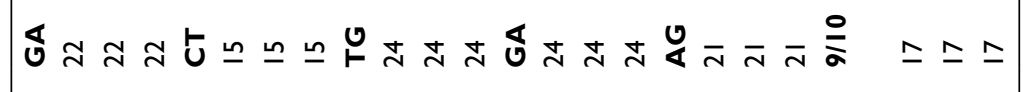

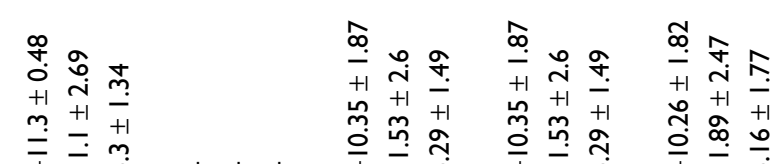

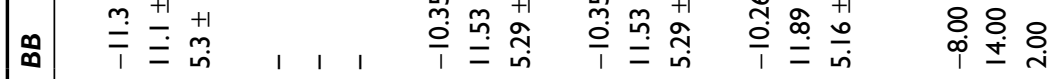

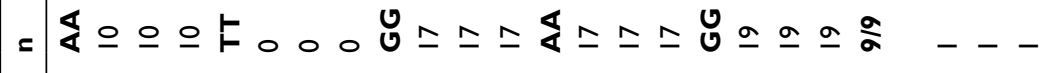

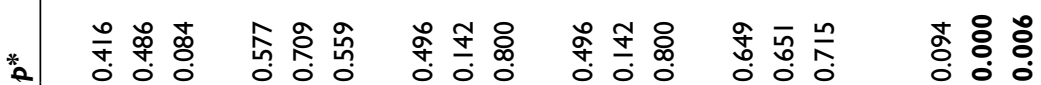

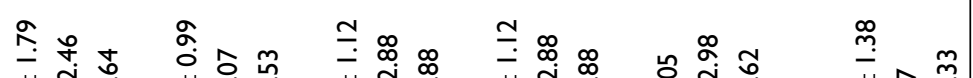

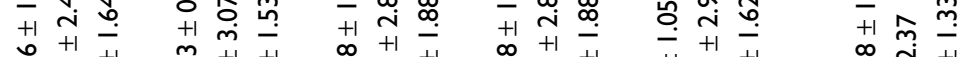
ஸे. \& 은 으

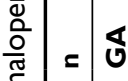

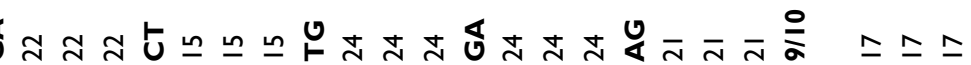

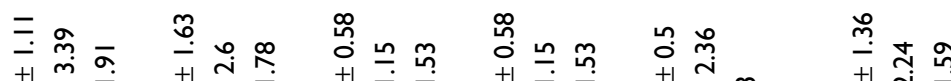

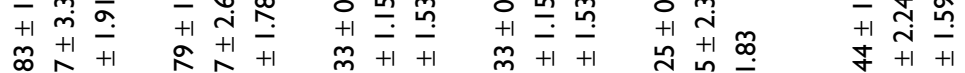

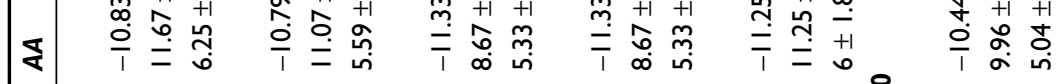
=

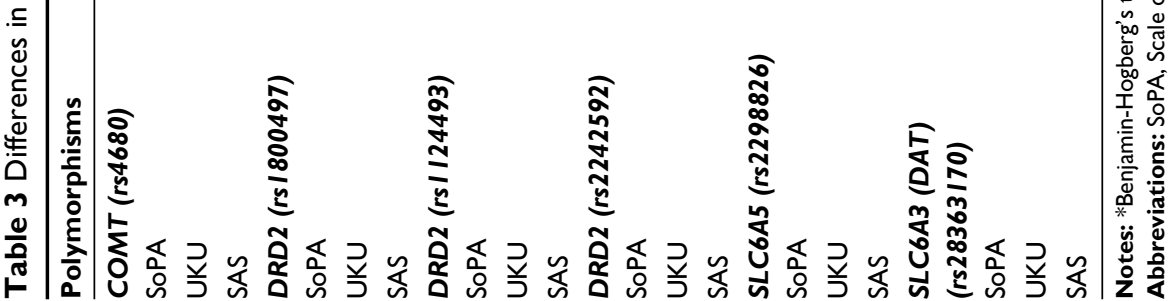




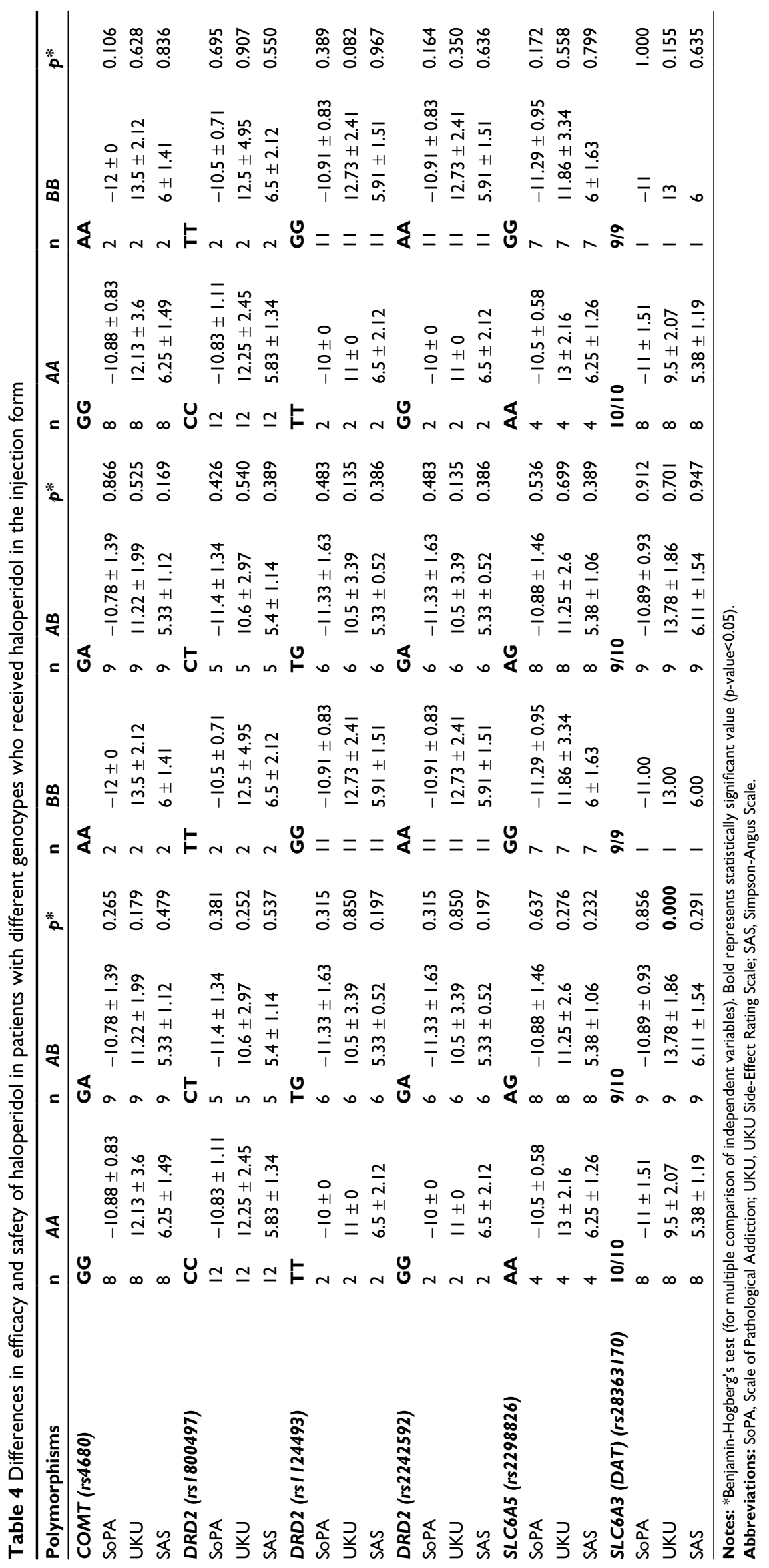


affect pharmacodynamics and pharmacokinetics of medication influencing the personal response to haloperidol, whereas some refute that.

The results of this study detected a statistically significant difference in the safety of haloperidol therapy in patients with genotypes $9 / 10$ and $10 / 10$ of polymorphic marker SLC6A3 rs28363170 receiving haloperidol for 5 days. This finding coincides with the results of two previously conducted studies in patients with schizophrenia. ${ }^{8,29}$ On the other hand, our results contrast with those obtained in some other studies. ${ }^{9,13,20,25}$

What are the reasons of these differences? Many relevant factors can affect gene expression, e.g., gender, race, concomitant therapy, diet, etc. For instance, the study conducted by Segman et $\mathrm{a}^{20}$ included the patients of Jewish population, whereas that conducted by Hori et $\mathrm{al}^{9}$ enrolled the Indian patients. This could affect not only the phenotype itself. It is important to note that the results of our study revealed no statistically significant difference in the efficacy of haloperidol therapy in patients with genotypes $9 / 10$ and 10/10 ( $p=0.094$ and $p=0.856$ for tablets and injections, respectively). This could be attributed to the changes in the density of $\mathrm{D}_{2}$ receptors in the extrapyramidal system only (but not in the mesolimbic system ${ }^{11,19,23}$ ) or to the low sensitivity of the scale used for efficacy assessment.

For other genes, the results of our study revealed no statistically significant differences among patients. In particular, there was no statistical significance of the rs4680 polymorphism of the COMT gene encoding the COMT synthesis. The results coincide with those obtained in other studies, ${ }^{14,24}$ although they differ from the conclusion of the meta-analysis. ${ }^{4}$ One of the probable reasons of this can be different population characteristics of the patients, especially different diagnoses: patients included in our study suffered from alcohol-use disorder, whereas meta-analysis included data obtained from the patients with schizophrenia. Why is it so important? According to meta-analysis data, ${ }^{10}$ a poorer performance on the continuous performance test and more small frontal and temporal brain areas have been associated with a COMT Val ${ }^{158}$ Met polymorphism in patients with schizophrenia. The authors suggest that val allele contributes to the development of the brain structural changes, which can be the substrate of underlying performance of continuous performance test.

The results of our study obtained for the DRD2 gene demonstrate no statistically significant difference between rs 1800497, rs1124493 and rs2242592 polymorphisms. They coincide with the results of the majority of studies exploring correlation between the polymorphism of this gene and haloperidol efficacy and safety. 5,7,17,29

We also explored the rs2298826 polymorphism of the SLC6A5 gene encoding a glycine transporter synthesis in the brain. One study ${ }^{6}$ revealed a strong statistical significance of acute ADR development in patients with schizophrenia receiving haloperidol $(p=0.0002)$. We found no other studies exploring the correlation between the SLC6A5 polymorphism and haloperidol efficacy and safety. In our study, we revealed no statistically significant difference. This could imply that changes in the synaptic glycine transporter activity in patients with alcohol-use disorder receiving haloperidol have no effect on haloperidol efficacy and safety.

It is important to note that pharmacokinetics can also affect the personal response to haloperidol. In our previous works, we showed the effect of CYP2D6 polymorphism (and its activity $)^{21}$ and the activity of CYP3A $4{ }^{28}$ on haloperidol efficacy and safety.

Thus, the adjustment of optimal haloperidol dose is a complex task, demanding the consideration of not only clinicodemographic factors but the pharmacogenetics also (polymorphism of the SCL6A3 gene and genes encoding the isoenzymes of haloperidol biotransformation).

\section{Conclusion}

Polymorphism of the SCL6A3 gene can affect the safety of haloperidol, and this should be taken into account during the choice of drug and its dosage regimen.

\section{Acknowledgments}

The authors are grateful to KB Mirzaev, JhA Avdeeva, JhA Sozaeva and NE Snalina at the research center of Russian Medical Academy of Continuous Professional Education of the Ministry of Health of the Russian Federation for assistance in the genotyping of patients. This work was supported by the Russian Science Foundation (project 16-15-00227: "Fundamental research and exploratory research in priority areas of research").

\section{Disclosure}

The authors report no conflicts of interest in this work.

\section{References}

1. NICE [webpage on the Internet]. Acute Alcohol Withdrawal. National Institute for Health and Care Excellence; 2015. Available from: http:// pathways.nice.org.uk/pathways/alcohol-use-disorders. Accessed June 10, 2017. 
2. Stewart S, Swain S; NICE; Royal College of Physicians, London. Assessment and management of alcohol dependence and withdrawal in the acute hospital, Royal College of Physicians. Clin Med. 2012;12(3): 266-271.

3. Bakker PR, van Harten PN, van Os J. Antipsychotic-induced tardive dyskinesia and polymorphic variations in COMT, DRD2, CYP1A2 and MnSOD genes: a meta-analysis of pharmacogenetic interactions. Mol Psychiatry. 2008;13(5):544-556.

4. Bozina N, Kuzman MR, Medved V, Jovanovic N, Sertic J, Hotujac L. Associations between MDR1 gene polymorphisms and schizophrenia and therapeutic response to olanzapine in female schizophrenic patients. J Psychiatr Res. 2008;42(2):89-97.

5. Dayalu P, Chou KL. Antipsychotic-induced extrapyramidal symptoms and their management. Expert Opin Pharmacother. 2008;9(9): 1451-1462.

6. Giegling I, Drago A, Dolžan V, et al. Glutamatergic gene variants impact the clinical profile of efficacy and side effects of haloperidol. Pharmacogenet Genomics. 2011;21(4):206-216.

7. Gunes A, Scordo MG, Jaanson P, et al. Serotonin and dopamine receptor gene polymorphisms and risk of extrapyramidal side effects in perphenazine-treated schizophrenic patients. Psychopharmacology. 2007;190(4):479-484.

8. Guzey C, Scordo MG, Spina E, et al. Antipsychotic-induced extrapyramidal symptoms in patients with schizophrenia: associations with dopamine and serotonin receptor and transporter polymorphisms. Eur J Clin Pharmacol. 2007;63(3):233-241.

9. Hori H, Ohmori O, Shinkai T, Kojima H, Nakamura J. Association between three functional polymorphisms of dopamine D2 receptor gene and tardive dyskinesia in schizophrenia. Am J Med Genet 2001;105(8):774-778.

10. Ira E, Zanoni M, Ruggeri M, Dazzan P, Tosato S. COMT, neuropsychological function and brain structure in schizophrenia: a systematic review and neurobiological interpretation. J Psychiatry Neurosci. 2013;38(6): 366-380.

11. Jonsson EG, Nothen MM, Grunhage F, et al. Polymorphisms in the dopamine D2 receptor gene and their relationships to striatal dopamine receptor density of healthy volunteers. Mol Psychiatry. 1999;4(3): 290-296.

12. Lachman HM, Papolos DF, Saito T, Yu YM, Szumlanski CL, Weinshilboum RM. Human catechol-O-methyltransferase pharmacogenetics: description of a functional polymorphism and its potential application to neuropsychiatric disorders. Pharmacogenetics. 1996;6(3): 243-250.

13. Lafuente A, Bernardo M, Mas S, et al. Dopamine transporter (DAT) genotype (VNTR) and phenotype in extrapyramidal symptoms induced by antipsychotics. Schizophr Res. 2007;90(1-3):115-122.

14. Lai IC, Wang YC, Lin CC, Bai YM, Liao DL, Yu SC. Negative association between catechol-O-methyltransferase (COMT) gene Val158Met polymorphism and persistent tardive dyskinesia in schizophrenia. J Neural Transm. 2005;112(8):1107-1113.

15. Männistö PT, Ulmanen I, Lundström K, et al. Characteristics of catechol O-methyl-transferase (COMT) and properties of selective COMT inhibitors. Prog Drug Res. 1992;39:291-350.
16. Matsumoto C, Shinkai T, Hori H, Ohmori O, Nakamura J. Polymorphisms of dopamine degradation enzyme (COMT and MAO) genes and tardive dyskinesia in patients with schizophrenia. Psychiatry Res. 2004;127(1-2):1-7.

17. Mihara K, Suzuki A, Kondo T, et al. No relationship between TaqIA polymorphism of dopamine D2 receptor gene and extrapyramidal adverse effects of selective D2 antagonists, bromperidol and nemonapride in schizophrenia: a preliminary study. Am J Med Genet. 2000;96:422-424

18. Neville M, Johnstone E, Walton R. Identification and characterization of ANKK1: a novel kinase gene closely linked to DRD2 on chromosome band 11q23.1. Hum Mutat. 2004;23(6):540-545.

19. Pohjalainen T, Rinne JO, Någren K, et al. The A1 allele of the human D2 dopamine receptor gene predicts low D2 receptor availability in healthy volunteers. Mol Psychiatry. 1998;3(3):256-260.

20. Segman RH, Goltser T, Heresco-Levy U, et al. Association of dopaminergic and serotonergic genes with tardive dyskinesia in patients with chronic schizophrenia. Pharmacogenomics J. 2003;3(5):277-283.

21. Sychev DA, Zastrozhin MS, Smirnov VV, Grishina EA, Savchenko LM, Bryun EA. The correlation between CYP2D6 isoenzyme activity and haloperidol efficacy and safety profile in patients with alcohol addiction during the exacerbation of the addiction. Pharmacogenomics Pers Med. 2016;9:89-95

22. Russian Society of Psychiatrists. The Standard of Specialized Medical Care in the Dependence Syndrome Caused by the Use of Psychoactive Substances. The Ministry of Health of Russian Federation; 2016:9. Available from: http://psychiatr.ru/download/2685? view=1\&name=302. pdf. Accessed June 10, 2017.

23. Thompson J, Thomas N, Singleton A, et al. D2 dopamine receptor gene (DRD2) Taql A polymorphism: reduced dopamine D2 receptor binding in the human striatum associated with the A1 allele. Pharmacogenetics. 1997;7(6):479-484.

24. Tsai HT, North KE, West SL, Poole C. The DRD3 rs6280 polymorphism and prevalence of tardive dyskinesia: a meta-analysis. Am JMed Genet B Neuropsychiatr Genet. 2010;153(1):57-66.

25. Xu M, Xing Q, Li S, et al. Pharmacogenetics effects of dopamine transporter gene polymorphisms on response to chlorpromazine and clozapine and extrapyramidal syndrome in schizophrenia. Prog Neuropsychopharmacol Biol Psychiatry. 2010;34(6):1026-1032.

26. Yoder KK, Hutchins GD, Morris ED, Brashear A, Wang C, Shekhar A. Dopamine transporter density in schizophrenic subjects with and without tardive dyskinesia. Schizophr Res. 2004;71(2-3):371-375.

27. Zai CC, De Luca V, Hwang RW, et al. Meta-analysis of two dopamine D2 receptor gene polymorphisms with tardive dyskinesia in schizophrenia patients. Mol Psychiatry. 2007;12(9):794-795.

28. Zastrozhin MS, Smirnov VV, Sychev DA, Savchenko LM, Bryun EA, Matis OA. CYP3A4 activity and haloperidol effects in alcohol addicts. Int J Risk Saf Med. 2015;27(suppl 1):S23-S24.

29. Zivković M, Mihaljević-Peles A, Bozina N, Sagud M, Nikolac-Perkovic M, Vuksan-Cusa B. The association study of polymorphisms in DAT, DRD2 and COMT genes and acute extrapyramidal adverse effects in male schizophrenic patients treated with haloperidol. J Clin Psychopharmacol. 2013;33(5):593-599.
Pharmacogenomics and Personalized Medicine

\section{Publish your work in this journal}

Pharmacogenomics and Personalized Medicine is an international, peerreviewed, open access journal characterizing the influence of genotype on pharmacology leading to the development of personalized treatment programs and individualized drug selection for improved safety, efficacy and sustainability. This journal is indexed on the American Chemical
Society's Chemical Abstracts Service (CAS). The manuscript management system is completely online and includes a very quick and fair peer-review system, which is all easy to use. Visit http://www.dovepress. com/testimonials.php to read real quotes from published authors. 